Beata Dobrzyńska*

Lipno

\title{
Rozumienie pojęć u dzieci w wieku przedszkolnym
}

\section{Wstęp}

Nauka mówienia to oswajanie i poznawanie świata samego i świata takiego, jakim go napotykamy.

(H. G. Gadamer)

Dzisiejsze przedszkole jest instytucją wychowania, opieki i działań dydaktycznych, która podąża za dzieckiem, wspiera jego wychowanie, wspomaga w rozwoju oraz współpracuje ściśle ze środowiskiem rodzinnym. Obecne przedszkole jest instytucją otwartą na innowacje pedagogiczne i prawdziwym wyzwaniem dla twórczej pracy nauczyciela.

Poznanie przez przedszkolaków całej otaczającej nas współczesnej rzeczywistości wymaga od nauczyciela zastosowania najbardziej celowych i współcześnie tworzonych metod; szczególnie w rozwoju myślenia i mowy. Główny nacisk we współczesnej edukacji kładzie się na twórcze myślenie i poprawne wypowiadanie się dzieci na określony temat. Jest to spowodowane modą na szybkie i niedbałe komunikowanie się. Wypowiedzi charakteryzuje ubogie słownictwo' ${ }^{1}$.

Nauczyciel przedszkola wpływa na rozwój mowy dziecka i powinien to być wpływ świadomy. Podejmowanie działań dydaktyczno-wychowawczych w zakresie doskonalenia i korygowania wymowy u wychowanków wymaga od nauczyciela jego

* Beata Dobrzyńska, dyplomowany nauczyciel-terapeuta Miejskiego Przedszkola nr 3 w Lipnie, doktorantka Uniwersytetu Mikołaja Kopernika w Toruniu, Zakład Pedagogiki Specjalnej.

${ }^{1}$ E. Kozłowska, M. Kurowska, Doradca nauczyciela sześciolatków. Materiaty metodyczne dla nauczycieli, Warszawa 2006, s. 3. 
poprawności w zakresie mowy, dbałości składni, wymowy. Mowa nauczyciela jest wzorem dla dziecka².

Twórcza aktywność w zakresie mowy dziecka powinna być kreowana przez nauczyciela przedszkola w celu optymalnego zrozumienia rzeczywistości - poznania, nazywania i definiowania ${ }^{3}$. Najbardziej korzystne warunki rozwoju mowy dziecka zapewnia ten nauczyciel, który bardzo dobrze zna swoich wychowanków, stwarza atmosferę bezpieczeństwa, wnosi dużo radości i optymizmu życiowego, poprawnie się wypowiada, aranżuje dużo zabaw w zakresie rozwoju mowy; stawia pytania, aby twórczo angażować dzieci do wypowiadania się; mówi do dzieci i potrafi ich słuchać, daje propozycje poprawnego wypowiadania się niż poprawia, każdą wypowiedź dziecka pochwala i ona daje mu radośćt.

\section{Co to znaczy rozumieć}

Dopóki rzecz nie ma nazwy, niepokoi człowieka stoi przed nim zagadkowa i zamknięta, nieprzystęna i nie dajaca się opanować, ale jeśli ma swoja nazwę to jest tak jakby człowiek ja znat i nie musiat sie już jej bać; [...]. Oto jakq wszechmocna i czarodziejskq sita jest nazwa!

(K. Capek)

To, czym jest mowa, możemy poprzeć definicjami. T. Zaleski5 ujmuje mowę jako układ symboli, znaków. Jednak łatwiej byłoby dla rozmówców pokazać dany przedmiot, zdarzenie, niż precyzyjnie to opisać za pomoca pojęć. Zagadnienie funkcji mowy u dzieci w wieku przedszkolnym ma szeroki zakres. Możemy rozpatrywać ją w aspekcie nauki mowy, błędów i wad wymowy, struktury wypowiedzi, zasobu słów oraz jaką potrzebą kieruje się dziecko, mówiąc nam o czymś. J. Piaget formułuje: „Mowa służy jednostce do komunikowania swoich myśli innym”. Dziecko wyrażania swoje myśli i spostrzeżenia wówczas, gdy rozumie, o czym mówi.

Potoczne użycie słowa r o z u m i e m może oznaczać to, co ujęto w świadomości/umyśle.

R o z u m i e ć s ło w o możemy używać w różnym kontekście. Słowo to elementarna część mowy. Jego pisanym odpowiednikiem jest wyraz. Za pomocą słów dokonujemy uogólnień, pozwalających na określenie pojęć rzeczywistych i abstrak-

${ }^{2}$ G. Demel, Minimum logopedyczne nauczyciela przedszkola, Warszawa 1996, s. 7.

${ }^{3}$ R. Michalak, E. Misiorna, Doradca nauczyciela sześciolatków. Materiaty metodyczne dla nauczycieli, Warszawa 2006, s. 36.

${ }^{4}$ E. Kozłowska, M. Kurowska, dz. cyt., s. 11.

${ }^{5}$ T. Zaleski, Opóźniony rozwój mowy, Warszawa 1992, s. 7.

${ }^{6}$ J. Piaget, Mowa i myślenie dziecka, Warszawa 2005, s. 31. 
cyjnych, także myślimy słowami. Słowa są składnikiem mowy, które mają zawsze znaczenie. Znaczenie - w najogólniejszym ujęciu jest to wiązka cech semantycznych, która tworzy określone struktury pojęciowe. Odnosi się do rozumienia pojęć. Pojęcie - abstrakcyjny, myślowy odpowiednik przedmiotu:

- w logice - znaczenie nazwy generalnej,

- w psychologii - umysłowa reprezentacja obiektów i zjawisk.

Pojęcie jest aktem myślowym - człowiek, przechodząc kolejne stadia, dojrzewa do posługiwania się myśleniem pojęciowym ${ }^{7}$. Po zdefiniowaniu pojęcie staje się terminem.

Pojęcia, które używamy, są naszym obrazem świata. Świadomość stosowania pojęć zgodnie $\mathrm{z}$ ich znaczeniem daje nam precyzję myślenia i mowy. $Z$ całego chaosu spostrzegania, zapamiętujemy tylko to, co potrafimy nazwać i ująć w pojęciu.

Zdaniem M. Czarnawskiej ${ }^{8}$, ,jeżeli nieświadomie zmieniamy treść pojęcia, rozumiejąc ją raz tak, raz inaczej, badany fragment rzeczywistości zacznie się wymykać naszemu poznaniu". Rozumieć język oznacza znać znaczenie słów i reguły, które je wiążą w sensowne zdania oraz nabycie kompetencji w zakresie ich użycia. To wyjaśnienie możemy przyjąć tylko wtedy, jeżeli znajomość semantyki, syntaktyki i fonetyki czyni język systemem.

Warunkiem rozumienia mowy jest przekaz; ,W akcie tym osoba mówiąca (nazwijmy ją nadawca) przekazuje informacje, a rozmówca (nazwijmy ją odbiorca) ją odbiera. Oba te procesy - przekazywanie informacji i jej odbiór, są możliwe tylko dzięki temu, że zarówno nadawca jak i odbiorca [...] znają ten sam [...] język"

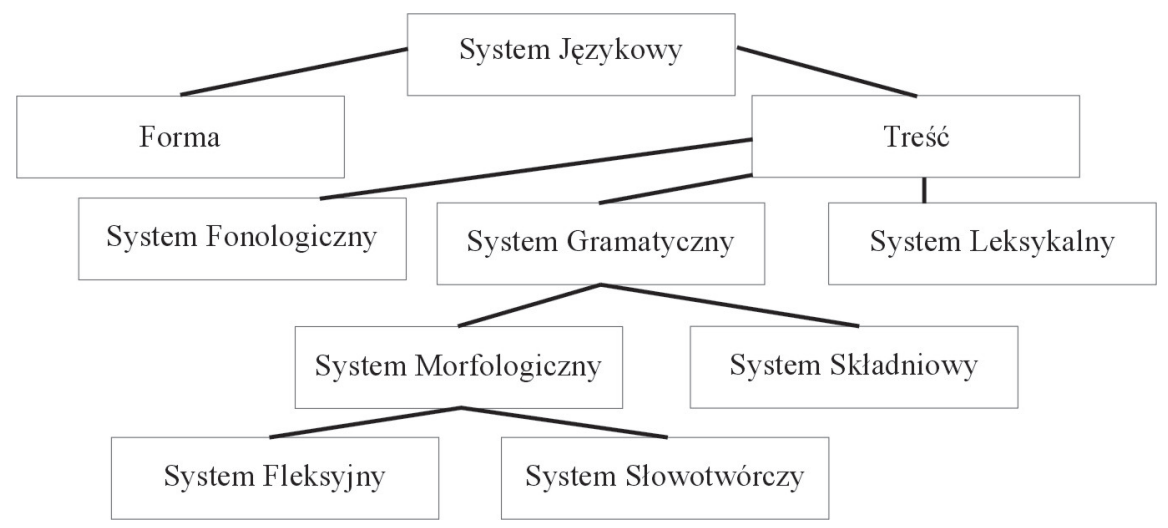

Wykres 1. System językowy wg Gołąb, Heinz, Polański ${ }^{10}$

${ }^{7}$ M. Marchow, Rola operacji znakowych w rozwoju, w: Nieobecne dyskursy, część VI, Wygotski z Wygotskim w tle, red. Z. Kwieciński, Toruń 2002 s. 39.

${ }^{8}$ M. Czarnawska, Kilka uwag o pojęciu rozumienia, w: Czynności tworzenia i rozumienia wypowiedzi, red. J. Porayski-Pomsta, Warszawa 2002, s. 118.

${ }^{9}$ L. Kaczmarek, Nasze dziecko uczy się mowy, Lublin 1988, s. 22.

${ }^{10}$ L. Smółka, Kompetencja komunikacyjna dzieci sześcio-siedmioletnich, Kraków 2004, s. 17. 
Rozumienie mowy jest częścią składową kompetencji komunikacyjnej.

Z psycholingwistycznego punktu widzenia kompetencję komunikacyjną traktuje się jako rozumienie mowy i produkowanie mowy. Powinna być ona powiązana z kompetencją językową ${ }^{11}$.

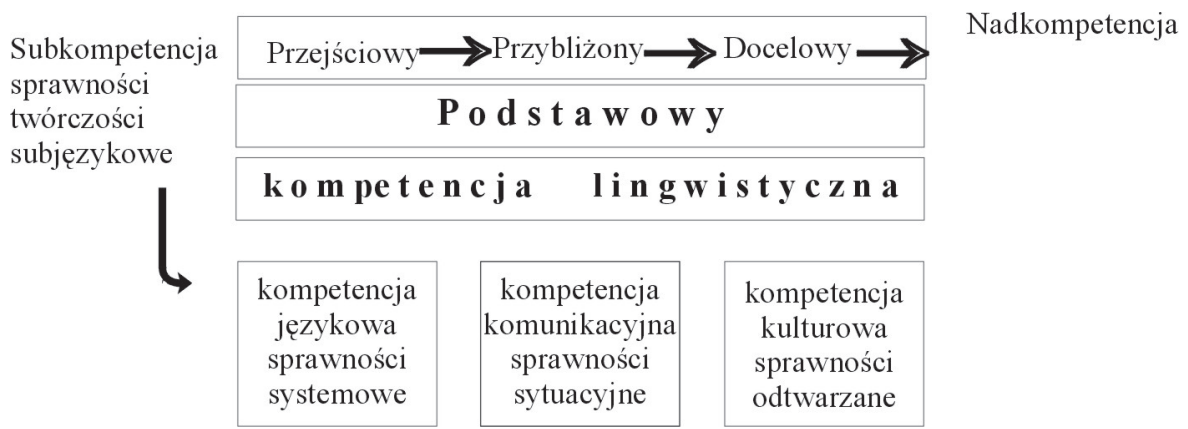

Wykres 2. Zintegrowany model kompetencji lingwistycznej wg T. Rittel ${ }^{12}$

Współczesne teorie psycholingwistyczne opisują proces opanowania mowy przez dziecko poprzez terminy:

1. Kompetencja językowa ${ }^{13}$ odnosi się do opanowania przez dziecko sprawności gramatyczno-leksykalnych. Wypowiedzi powinny być poprawne pod względem gramatycznym, a słownik czynny bogaty.

2. Kompetencja komunikacyjna ${ }^{14}$ wskazuje, czy dziecko stosuje formę wypowiedzi adekwatną do sytuacji, intencji oraz do słuchacza.

3. Kompetencja kulturowa jest budowana u dziecka przez jego ogólną wiedzę, spostrzeżenia i nawyki ${ }^{15}$.

\section{Rozwój językowy u dzieci - teorie}

Rozmowy nie można nauczyć, do rozmowy należy wychowywać.

(ks. Andrzej Zwoliński)

W latach sześćdziesiątych główną teorią rozwoju językowego był behawiorystyczny model B. F. Skinnera, który ujmował proces nabywania języka w kategorii uczenia się poprzez warunkowanie.

${ }^{11}$ Tamże, s. 17.

${ }^{12}$ Tamże, s. 51.

${ }^{13}$ Termin ten wprowadził twórca gramatyki generatywnej N. Chomsky. Por. G. Shugar, M. Smoczyńska, Badania nad rozwojem języka dziecka. Wybór tekstów, Warszawa 1980, s. 35.

${ }^{14}$ Pojęcie to wprowadzone zostało przez przedstawiciela socjolingwistyki D. Hymesa. Por. G. Shugar, M. Smoczyńska, dz. cyt., s. 35.

${ }^{15}$ L. Smółka, dz. cyt., s. 51. 
W pojawiających się późniejszych teoriach wyróżniamy model etnologiczny N. Chomskiego, reprezentowany przez teorię psycholingwistyczną. Według niej dziecko nie uczy się języka przez naśladowanie. Ważny jest tu mechanizm aktywizacji mowy, który jest wrodzony, zwany LAD. Istotna w tym modelu reprezentacja semantyczna jest taka sama dla ludzi posługujących się różnymi językami. Zgodnie z tą teorią uczenie się języka jest niezależne od rozwoju poznawczego dziecka. Kompetencja językowa w tym modelu ma charakter formalny i nie odnosi się do znaczenia wypowiedzi. Chodzi tu o twórczy aspekt nabywania języka ${ }^{16}$.

Ciekawa jest koncepcja genu gramatycznego S. Pinkera. Według niej, istnieje gen gramatyczny. W mózgu znajduje się pewna sekwencja DNA, która jest odpowiedzialna za tworzenie języka, wypowiedzi ${ }^{17}$.

Teoria poznawczo-rozwojowa J. Piageta zakłada, że rozwój sensoryczno-motoryczny idzie w parze z osiagnięciami w opanowaniu języka. Ważne są wczesne zdolności przedoperacyjnych. Również J. S. Bruner był zwolennikiem tej teorii i twierdził, że rozwój języka nie jest autonimiczny i zależy włączyć go do poznawczego i społecznego rozwoju języka ${ }^{18}$.

Proces nabywania znaczeń próbował wyjaśnić E. Clark. Koncepcja czynników semantycznych opisuje proces budowania znaczenia przez dzieci. Odbywa się ten proces poprzez sukcesywne poznawanie cech obiektu - właściwości:

1) od znaczeń o jednej właściwości percepcyjnej do znaczeń zawierających wiele różnych cech,

2) od znaczeń prostych do znaczeń złożonych,

3) od znaczeń o cechach pozytywnych do znaczeń o cechach negatywnych,

4) od znaczeń ogólnych do znaczeń o cechach szczegółowych,

5) od znaczeń opartych na systemie poznawczym dziecka do znaczeń opartych na systemie semantycznym ${ }^{19}$.

Twórcą koncepcji funkcjonalnego jądra jest K. Nelson. W tym ujęciu poznanie przez dziecko - jego system poznawczy jest punktem wyjścia do ustalania znaczeń w mowie. Działanie służy kierowaniu uwagi na istotne cechy przedmiotu, którym bawi się dziecko - cechy funkcjonalne. W związku z tym pierwsze słowa dziecka związane są z działaniem ${ }^{20}$.

Koncepcja kategorii semantycznych według E. Rosch i M. Kielar-Turskiej tłumaczy, iż znaczenie w mowie budowane jest na podstawie e 1 e m e n t u p r o t o t yp o w e g o. Zawsze wybiera się najlepszy przykład z danej kategorii, aby wyjaśnić dziecku nowe pojęcie. Dzieci spostrzegają dany przedmiot i charakteryzują nazwę podstawową, natomiast w nazwach nadrzędnych wymagane są informacje ogólniej-

\footnotetext{
${ }^{16}$ Tamże.

${ }^{17}$ Tamże, s. 16.

${ }^{18}$ J. Piaget, dz. cyt., s. 27.

${ }^{19}$ L. Smółka, dz. cyt., s. 17.

${ }^{20}$ Tamże, s. 32.
} 
sze i właściwe dla całej grupy w danej kategorii nadrzędnej i dlatego jest to możliwe, gdy myślenie dziecka będzie miało charakter słowno-logiczny ${ }^{21}$.

Koncepcja neuropsychologicznego podłoża mówienia według A. Łurii traktuje ten proces jako złożony system funkcjonalny o genezie społecznej. Czynnościowy układ mowy realizuje się poprzez złożone zespoły współpracujących ze sobą okolic mózgu ${ }^{22}$.

\section{Wypowiedzi u dzieci w wieku przedszkolnym}

Mowa jest wysoce diagnostycznym wskaźnikiem ogólnego rozwoju,
soczewka, w której skupia się niemal cały obraz rozwoju.
Toteż badając mowę, poznajemy właściwie cate dziecko.

(G. Demel)

Okres przedszkolny od 3 do 7 lat jest wiekiem, kiedy dziecko ma już wiedzę o sobie, środowisku rodzinnym, przedszkolnym oraz pozaprzedszkolnym. Poszerzają się wówczas kontakty społeczne, co powoduje rozwój mowy i nabywanie doświadczeń. Na każdym etapie rozwoju mowy, a szczególnie w wieku przedszkolnym, ujawnia się wiedza o świecie i wiedza o języku ujęta w sposób praktyczny, wykorzystywana na miarę swoich potrzeb i możliwości. W pierwszych siedmiu latach życia dziecka obserwuje się największe postępy w zdobywaniu kompetencji komunikacyjnej. Choć bardzo ważny jest okres prelingwalny - gdy dziecko dostrzega potrzebę komunikowania się ze swoim otoczeniem, odkrywa istotę znaku językowego - do 10 miesiąca życia. Okres lingwalny rozpoczyna się w momencie praktycznego opanowania przez dziecko pojęcia znaku językowego i trwa do przyswojenia podstaw systemu językowego ${ }^{23}$. Poszczególne składowe kompetencji nie rozwijają się równomiernie. Dzieci 3-4-letnie mogą dość swobodnie porozumiewać się z otoczeniem, natomiast 5-6letnie potrzebują już doskonalenia swoich wypowiedzi, aby były jeszcze bardziej precyzyjne.

Trzylatek ustawia w centrum świata siebie, swoich bliskich i znajomych. Często pojawiają się pojęcia, które można zaliczyć do kategorii nadrzędnej, podrzędnej oraz używa nazw własnych. W wypowiedzi 3-latek posługuje się pojęciami, które porządkują jego świat i próbuje utworzyć pewne kategorie ${ }^{24}$. Granice te są bardzo nieprecyzyjne i trudne do zdefiniowania jako pojęcia. Należy to wytłumaczyć rozwojem myślenia i mowy, a także małą pojemnością pamięci ${ }^{25}$.

Dzieci czteroletnie tworzą dłuższe wypowiedzi w bezpośredniej reakcji słownej na pytania, prośby, polecenia. Również w mowie spontanicznej. Dzieci mówią wię-

${ }^{21}$ M. Kielar-Turska, Język dziecka. Stowo i tekst, Kraków 1989, s. 41.

${ }^{22}$ G. Krasowicz-Kupis, Język, czytanie, dysleksja, Lublin 2003, s. 25.

${ }^{23}$ J. Porayski-Pomsta, Umiejętności komunikacyjne u dzieci w wieku przedszkolnym. Studium psycholingwistyczne, Warszawa 1994, s. 49-50.

${ }^{24}$ M. Kielar-Turska, dz. cyt., s. 127.

${ }^{25}$ B. Boniecka, Ksztalt dziecięcego słowa, Lublin 1997, s. 93. 
cej na dany temat, wypowiedzi ich są poprawniejsze syntaktycznie. Strona semantyczna bardziej urozmaicona, a określenia trafniejsze i dokładniejsze. W tym wieku zaznacza się silna potrzeba tworzenia kategorii, zbiorów i uogólnieńn ${ }^{26}$.

Pięciolatki opisują obrazki, zauważają i wymieniają liczbę przedmiotów lub postaci. Starają się mówić pełnym zdaniem. Większość dzieci w tym wieku określa czas, miejsce, przyczynę i skutek. Używają pojęcia, które należą do kategorii podstawowej, rzadko tworzą neologizmy. Wyraźnie uświadamiają sobie i posługują się pojęciami podrzędnymi i nadrzędnymi. W wypowiedziach dzieci tej grupy wiekowej pojawiają się często czasowniki, wyrażenia określające nastrój psychiczny, emocje. Pojawia się większy zasób przymiotników ${ }^{27}$. Dziecko w tym wieku przywiązuje duże znaczenie do wielkości. Dość ważne jest określanie kolorów, choć rok wcześniej było to nieistotne ${ }^{28}$. Organizacja świata na zasadzie rodziny zostaje poszerzona o nowe doświadczenia. Dzieci nie zauważają cech ujemnych - o pejoratywnym znaczeniu, ale bardzo często stosują określenie „fajny”.

W grupie dzieci sześcioletnich słownictwo jest już zróżnicowane pod względem formalnym. Sześciolatek wyraża się przez różne części mowy. Licznie występują n e o$\log$ i z m y ${ }^{29}$ i neosemantyz my . $^{30}$.

W zakresie przyswajania i rozumienia pojęć u dzieci w wieku przedszkolnym zauważa się trudności wielorakiego rodzaju:

1) niezdolność do opanowania pojęć zgodnie z normą wiekową (subkompetencja) od strony fonologicznej,

2) niezdolność do używania pojęć zgodnie z ich desygnatami,

3) niezdolność do stosowania pojęć w zdaniach zgodnie z regułami syntaktycznymi,

4) nadkompetencja językowa ujawnia u dzieci uzdolnionych językowo, skupia się na ich kreatywności językowe ${ }^{31}$,

5) dla dziecka w wieku przedszkolnym typowa jest kompetencja przejściowa, od której dziecko odchodzi, gdy osiagga dojrzałość szkolną w wieku 7 lat. Cechą charakterystyczną dla niej jest „produkowanie” zdań, które akceptuje środowisko, ale nie są jeszcze poprawne gramatycznie. Dziecko najpierw pragnie powiedzieć to, co widzi lub opowiedzieć o zdarzeniu, którego było świadkiem, zaś później myśli nad sposobem wyrażenia myśli. W okresie tym dziecko mówi to, co myśli. Dla niego myśl to mowa, a mowa to słowa (pojęcia). Przedszkolak jest realistą. Występuje również

${ }^{26}$ J. Porayski-Pomsta, dz. cyt., s. 61.

${ }^{27} \mathrm{~K}$. Bułczyńska, Wiek jako czynnik różnicujacy zasób przymiotników i przysłówków w mowie dzieci przedszkolnych, w: Zagadnienia komunikacji językowej dzieci i młodzieży. Materiały ogólnopolskiej konferencji, red. J. Porayski-Pomsta, Warszawa 1991, s. 55-62.

${ }^{28}$ A. Maciejewska, Formowanie znaczeń w wypowiedziach dzieci przedszkolnych, w: Czynności tworzenia i rozumienia wypowiedzi, red. J. Porayski-Pomsta, Warszawa 2002, s. 66-67.

${ }^{29}$ Pojęcie to oznacza nowotwór językowy, znaczenie wyrazu nowo utworzone w danym języku. Por. Słownik wyrazów obcych, red. J. Tokarski, Warszawa 1980, s. 506.

${ }^{30}$ Termin ten oznacza wyraz, który otrzymał nowe znaczenie czyli neologizm semantyczny. Por. Slownik wyrazów obcych, s. 507.

${ }^{31}$ L. Smółka, dz. cyt., s. 15. 
w tym okresie skłonność do nadawania życia istotom nieożywionym. Swoje odczucia, cechy i emocje przekazują wszystkim - rzeczom, zwierzętom, zjawiskom przyrodniczym $^{32}$.

Dziecko przedszkolne w poznawaniu pojęć kieruje się do przedmiotów i osób, które je interesuje. Myśli głównie za pomocą oczu, uszu i rąk. Musi zobaczyć, usłyszeć i dotknąć, aby zrozumieć pojęcie. Jest to tzw. pedagogika małego Koziołka ${ }^{33}$.

\section{System semantyczny}

Żeby naprawić świat,
najpierw trzeba poprawić język.
(Konfucjusz)

Rozwój systemu semantycznego oznacza przyswajanie sobie słów i ich znaczenia. Jeżeli dziecko potrafi do przedmiotu przyporządkować jego nazwę, to możemy mówić o opanowywaniu przez niego semantyki. Ten moment rozwoju przypada już na czwarty kwartał pierwszego roku życia, dziecko rozumie więcej słów, niż potrafi je nazwać.

Według L. Wygotskiego rozwój mowy i myślenia przebiega w pierwszym roku życia jakby oddzielnie. Jak twierdzi autor, istnieje $\mathrm{m}$ y śl e $\mathrm{n}$ i e $\mathrm{n}$ i e w e r b a $l \mathrm{n}$ e i mowa n i e in te le k t u a $\mathrm{ln}$ a. Te dwie linie rozwijają się osobno. W drugim roku zaczynają się krzyżować34.

Każdy nowy przedmiot stanowi dla dziecka sytuację zadaniową. Nie zawsze jest w stanie rozwiązać to zadanie, gdyż może występować różnica pomiędzy wiedzą o świecie a wiedzą językową. Stąd dziecko używa pojęcia (etykiety) dla desygnatów, które mają inną nazwę, czyli tzw. n a d p r o d u k c j ę. Zjawisko tego błędu językowego wystęuje najczęściej do 3 roku życia i tylko w procesie stosowania nazw.

W wieku przedszkolnym dzieci mają problemy ze zjawiskami językowo-semantycznymi jak s ynonimicznoś $\mathrm{c}^{35}$, homonimicznoś $\mathrm{c}^{36}$, metaforyczn o ś ć ${ }^{37}$. Rozwój systemu semantycznego jest związany ściśle ze specyfiką kształtowania się w tym wieku myślenia, które przepełnione są dziecięcym realizmem, animizmem oraz artyficjalizmem.

${ }^{32}$ D. Al-Khamisy, Rozwijanie pojęć przyrody nieożywionej u dzieci sześcioletnich, Warszawa 1996, s. 29-33.

${ }^{33}$ M. Debesse, Etapy wychowania, Warszawa 1995, s. 61.

${ }^{34}$ Nieobecne dyskursy, część VI, Wygotski z Wygotskim w tle, red. Z. Kwieciński, Toruń 2000, s. 35 .

${ }^{35}$ Oznacza wyraz bliskoznaczny. Por. Stownik wyrazów obcych..., s. 722.

${ }^{36}$ Inaczej wyraz równobrzmiący, lecz mający odmienne znaczenie, etymologię. Por. Stownik wyrazów obcych..., s. 286.

${ }^{37}$ Wyrażony za pomocą metafory, przenośni. Por. Słownik wyrazów obcych..., s. 469. 
Pamięć semantyczna nie jest według Z. Chlewińskiego „pasywnym magazynem informacji, nie działa na zasadzie taśmy magnetofonowej, rejestrującej wszelkie informacje" ${ }^{" 38}$. Pojęcia są podstawą w rozumieniu i wnioskowaniu.

\section{Kształtowanie pojęć w wieku przedszkolnym}

Nauczanie jest tylko wtedy efektywne, gdy wyprzedza rozwój, który wówczas ożywia się i pobudza do życia szereg funkcji dopiero dojrzewajacych, a leżacych w strefie najbliższego rozwoju.

(L. Wygotski)

Proces kształtowania pojęć nazywany jest w psychologii t w o r z e n i e m pojęć. Termin ten stosowany jest głównie w celu badania małych dzieci. Uczenie się nowych słów, zwrotów tworzy słownik bierny i czynny dziecka, zaś zapoznanie się $\mathrm{z}$ ich definicjami uściśla ich zakres ${ }^{39}$.

Wiek przedszkolny jest czasem, kiedy dzieci pragną wszystko nazywać, nadawać imiona, etykiety. Interpretacja świata zależy od ich języka i odwrotnie język dzieci, pojęcia i sposób mówienia zależy od spostrzegania i analizowania świata, który ich otacza. Sam proces kształtowania pojęć jest bardzo złożony i zależy od wpływu środowiska rodzinnego i organizowania oddziaływań wychowawczo-dydaktycznych w placówce przedszkolnej.

Temat ten analizowała M. Kielar-Turska ${ }^{40}$, która wyodrębniła kilka subpotrzeb poznawczych charakterystycznych dla wieku przedszkolnego, a niezbędnych do przyswajania i rozumienia pojęć. Są to:

1) potrzeba eksploracji - dziecko zbliża się do obiektu, który jest dla niego celem bliższego poznania, poznaje właściwości, zadaje pytania,

2) potrzeba etykietowania - dziecko nadaje nazwę obiektowi i przez to uznaje, że go zna,

3) potrzeba świeżości - dziecko pragnie wiedzieć czym różni się dany obiekt od innych,

4) potrzeba rzeczy znanych - dziecko chce powtarzać rzeczy już znane, aby utrwalić oczekiwany rezultat,

5) potrzeba pytania - dziecko zadaje pytania, aby zaspokoić swą ciekawość i zwrócić na siebie pytania,

6) potrzeba obrazu świata - dzieci wypowiadają się na określony temat wskazany przez słuchacza, w zakresie którego posiadają wiedzę.

38 Z. Chlewiński, Ksztaltowanie się umiejętności poznawczych. Identyfikacja pojęć, Warszawa 1999, s. 139.

${ }^{39}$ Tamże, s. 21.

${ }^{40}$ L. Smółka, dz. cyt., s. 70. 
Natomiast D. Al-Khamisy ${ }^{41}$ wskazuje, iż „kształtowanie się wyobrażeń sprzyja uściśleniu i zróżnicowaniu pojęć. Nie zawsze jednak u dzieci, zwłaszcza w wieku przedszkolnym, da się wyraźnie wskazać granicę między wyobrażeniową a pojęciowa reprezentacja przedmiotów".

Podobne są kierunki rozwoju pojęć u dzieci w wieku przedszkolnym, ale poziom rozwoju pojęć nie jest jednakowy, jednolity. W procesie przyswajania pojęć dziecko przechodzi od pojęć prostych do złożonych, czyli rozumie pojęcia nadrzędne; przechodzi od pojęć ogólnych do szczegółowych czyli uczy się pojęć podrzędnych oraz nabywa umiejętność definiowania pojęćc ${ }^{42}$. Definiowanie pojęć jest złożoną czynnością myślenia dziecka, gdyż oderwana jest od konkretnej sytuacji, rzeczywistości. Opiera się bardzo często na abstrakcji ${ }^{43}$. W wieku przedszkolnym występuje kojarzenie nazw z odpowiadającymi im desygnatami (rozpoczyna się ten proces już od wieku poniemowlęcego) oraz tworzenie przedpojęć, które powstają na zasadzie znajomości cech zewnętrznych. W. Okoń określa ten etap - tworzenie pojęć elementarnych.

\title{
Rozumienie pojęć religijno-chrześcijańskich u przedszkolaków
}

\author{
Trzeba by być Bogiem, aby odpowiedzieć \\ na wszystkie pytania dziecka...
}

(M. Debesse)

Kształtowanie się u dzieci w wieku przedszkolnym pojęć o charakterze religijnym i ich rozumienie jest ściśle związane z artyficjalizmem. Według Stownika wyrazów obcych, pojęcie to z łaciny oznacza sztuczny, zaś w aspekcie psychologicznym to przekonanie u dzieci w wieku przedszkolnym, że niektóre przedmioty i zjawiska przyrody są według kogoś $\mathrm{w}$ jakimś celu zrobione; świat został stworzony przez człowieka lub jaką́ istotę wyższą dla zaspokojenia potrzeb ludzkich. Między 5 a 6 rokiem życia, a więc kiedy w placówkach przedszkolnych rozpoczynają się zajęcia z religii, wówczas dziecko uważa, że wszystko to, co go otacza jest zrobione przez lub dla człowieka. Dla człowieka wszystko tworzy BÓG lub DRUGI CZŁOWIEK.

Podziału artyficjalizmu dziecięcego na cztery typy dokonał J. Piaget. W myśleniu dzieci w wieku przedszkolnym dominują:

1) artyficjalizm rozsiany - dziecko nie zastanawia się jeszcze wówczas nad pochodzeniem rzeczy, nie potrafi odpowiedzieć na pytanie dotyczące pochodzenia rzeczy, ani również nie wykazuje potrzeby pytania o pochodzenie;

2) artyficjalizm mitologiczny - przedszkolak zaczyna stawiać sobie pytania dotyczące pochodzenia przedmiotów, przyrody ożywionej i nieożywionej, pojawiają się

\footnotetext{
${ }^{41}$ D. Al-Khamisy, dz. cyt., s. 15.

${ }^{42}$ Tamże.

${ }^{43}$ W. Okoń, Wprowadzenie do dydaktyki ogólnej, Warszawa 1995, s. 144.
} 
wówczas różne mity w myślach dzieci stworzone dla swoich potrzeb wytłumaczenia pochodzenia rzeczy, zjawisk ${ }^{44}$;

3) podczas przedszkolnych zajęć nauczania religii nie wystarczy tylko teoretycznie uczyć o tym, że Bóg stworzył świat. Należy wykorzystywać formy i metody pracy wychowania przedszkolnego, aby przybliżyć dzieciom pojęcia i symbolikę. Bardzo dobrze sprawdzają się inscenizacje dziecięce, w których przedszkolaki ukazują obrzędy i zwyczaje chrześcijańskie, a poprzez które mogą zrozumieć symboliczny charakter niektórych pojęć chrześcijańskich. „W katechezie dla najmłodszych to właśnie praktyczne wykorzystanie symboliki rzeczywistości stworzonej, wydaje się bardzo ważne. Zanim bowiem dziecko zrozumie cokolwiek z Pisma Świętego, że taka księga w ogóle istnieje, od pierwszych chwil swego życia doświadcza stale i na różny sposób otaczającą je rzeczywistość, wrasta w nią, poznaje, jest na nią otwarte i chłonie wszystkimi zmysłami. Doświadczenia te bogacą i kształtują jego osobowość, zapadają głęboko w psychikę, gdzie są przechowywane i przetwarzane"45;

4) nauczanie pojęć chrześcijańsko-religijnych nie powinno ograniczać się do wtajemniczania w świat biblijny od strony czysto formalnej, ale winno być zaplanowanym szeregiem oddziaływań nauczania, prowadzonym systematycznie i w sposób zamierzony. Bardzo ważny jest tutaj proces wzrastania w świat symboliki, który poparty jest religijną świadomością środowiska rodzinnego dziecka. W życiu ludzi i otaczającym nas świecie jest wiele elementów biblijnych. Proces wrastania w symbolikę religijną, biblijną rozpoczyna się już po urodzeniu. Początkowo nie uświadamiamy sobie tego, a tym bardziej w żaden sposób nie kształtujemy według reguł pedagogiczno-katechetycznych. Rodzina kształtuje pierwotne pojęcia w zakresie życia chrześcijańskiego, symboliki biblijnej $\mathrm{i}$ to wrastanie w rzeczywistość stworzoną przez B o g a dokonuje się w sposób ciaggły i najczęściej pozbawiony dydaktyzmu ${ }^{46}$.

W wieku przedszkolnym dzieci pytają więcej niż kiedykolwiek. Szukają tajemnic między 3 a 6 rokiem życia. Jest to zrozumiałe, gdyż to wiek pytań. Pytania dotyczą również tajemnic istnienia. Wówczas wzbogaca się ich słownik bierny i czynny. Już 4- i 5-latki pytają o początek i cel życia, o życie i śmierć. W wypowiedziach dzieci dominują tematy i pojęcia związane $z$ istnieniem Boga. B ó g i ś m i e r ć stanowią motywy przewodnie. Dzieci pragną poznawać i rozumieć pojęcia związane z następującymi problemami:

1) istnienie Boga, Jego istota i forma - Bóg jest ojcem, tak jak tata, tylko że On to jest Bóg [dz. 4 lata],

2) wielkość, niewidoczność, wszechmoc, nieprzemijalność i obecność Boga - Gdzie Bóg jest teraz? - A to trudno powiedzieć, Bóg jest taki ogromny. - Czy jest tak duży jak nasz tata? [dz. 4 lata],

3) co to znaczy wykraczać poza świat, tkwić w świecie - Czy w powietrzu jest jeszcze inny świat? A pod ziemia, jeśli się kopie gtęboko? [dz. 5 lat],

\footnotetext{
${ }^{44}$ D. Al-Khamisy, dz. cyt., s. 33-34.

${ }^{45}$ W. Kubik, Jezus Chrystus z nami, cz. II, Warszawa 1984, s. 25.

${ }^{46}$ Tamże, s. 25.
} 
4) jak powstał Bóg, człowiek i jego dusza, narodzenie i śmierć - To nie jest takie straszne, umrzeć; Bóg może cię znowu przywrócić do życia. On to potrafi [chł. 5 lat],

5) cierpienie i kontakt z Bogiem - Dzieci zobaczyly martwego ptaka: On pójdzie dziś wieczorem do Boga. - Nie, niezupetnie, tylko jego oczy i coś ze środka [chł. 5 lat],

6) miłość Boga, modlitwa, narodziny Chrystusa, Jego śmierć i zmartwychwstanie - Spacerowatem ostatnio w lesie; byto mi tak dobrze, że chciatem pocałować Pana Boga [chł. 8 lat],

7) piekło, niebo, koniec świata - Koniec świata to Bóg [chł. 5 lat],

8) dobro i zło, aniołowie i diabeł - Kto to jest anioł i jak wyglada? - Nie, to nie jest on, to jest światto od środka; zaczynam wtedy śpiewać - po głębokim namyśle - albo podskakiwać [dz. 7 lat],

9) Biblia i Kościół - Nigdy nie otrzymuję odpowiedzi, kiedy się modlę, a w Biblii jest napisane, że Bóg odpowiada [dz. 8 lat $]^{47}$.

\section{Wnioski}

A niechaj mowa wasza będzie: tak, tak, nie, nie.

(Mt 5, 37a)

$\mathrm{Na}$ tle pracy dydaktyczno-wychowawczej oraz obserwacji pedagogicznej dzieci w wieku przedszkolnym zauważa się te, które potrzebują specjalnych potrzeb edukacyjnych w zakresie rozwoju semantycznego. Są to dzieci z trudnościami w rozumieniu mowy i także uzdolnione językowo.

Zdaniem A. Maslowa najlepszą drogą ogólnego poznawania jest stymulowanie rozwoju dziecka. Jednak, aby dziecko było ciekawe świata, należy zaspokoić jego podstawowe potrzeby. Potrzeba jest warunkiem prawidłowego funkcjonowania dziecka ${ }^{48}$.

Wspomniany autor uporządkował potrzeby według hierarchii. Najpierw powinny być zaspokojone potrzeby biologiczne, bezpieczeństwa, miłości, potem uznania, samorealizacji, poznawcze i estetyczne. Dziecko, u którego są zaspokojone potrzeby szczególnie ciepła, sytości, miłości i stałości jest ciekawe świata, otwarte na poznawanie $^{49}$.

Na podstawie Programu wychowania przedszkolnego dla dzieci 3-6-letnich ${ }^{50}$ oraz autorskich programów terapeutycznych opracowuje się indywidualną pomoc wspomagającą rozwój pojęć u dzieci na etapie edukacji elementarnej, wówczas gdy jego kompetencja lingwistyczna ma charakter rozwojowy, czyli przejściowy.

47 J. Klink, Wierzyć z dziećmi, Warszawa 1989, s. 24-121.

${ }^{48} \mathrm{~J}$. Wyczesany, A. Mikruta, Kształcenie zintegrowane dzieci o specjalnych potrzebach edukacyjnych, Kraków 2002, s. 76.

49 J. Wyczesany, A. Mikruta, dz. cyt., s.76.

${ }^{50}$ H. Czerniawska, Program wychowania przedszkolnego dla dzieci 3-6-letnich, Warszawa 2001, s. 22. 
Zajęcia terapeutyczne mieszczą się głównie w zakresie:

1) subkompetencji i skierowane byłyby do dzieci, które nie mogą opanować języka zgodnie z normą wiekową i potrzebują specjalistycznej pomocy w zakresie logopedii,

2) zabaw i ćwiczeń słownikowych,

3) zabaw i ćwiczeń gramatycznych,

4) zabaw i ćwiczeń aktywizujących myślenie twórcze dzieci uzdolnionych.

Ważne jest, aby w toku codziennej pracy dydaktycznej i oddziaływań wychowawczych z przedszkolakami organizować jak najwięcej sytuacji, w których mają okazję poznawać pojęcia, nazywać przedmioty, zjawiska, określać sytuacje i stany emocjonalne. Nauczyciele przedszkoli, w ścisłej współpracy z rodzicami i środowiskiem rodzinnym winni iść przed dzieckiem - wskazywać i nazywać po imieniu to, co im nieznane. Przykładem mogą być twórcze gry multimedialne ${ }^{51}$. Zabawa w nich połączona jest z poznawaniem pojęć religijno-chrześcijańskich. Napisane są specjalnie dla małych dzieci w wieku przedszkolnym; jest to nowy i ciekawy sposób połączenia techniki z tradycją, czyli ukazanie Pisma Świętego - Świata Księgi nad Księgami w sposób przystępny dla przedszkolaka, dostosowany do możliwości rozwojowych i programu wychowania przedszkolnego.

\section{Begriffverstehen bei den Kindern im Kindergartenalter (Zusammenfassung)}

In dem Artikel wird das Begriffverstehen bei den Kindern im Kindergartenalter besprochen. Es wird auf die besondere Rolle des Kindergartens als einer Anstalt in der Unterstützung der Kinderentwicklung, auch Sprachentwicklung hingewiesen. Einen erzieherisch-didaktischen Erfolg kann nur eine enge Zusammenarbeit mit dem Elternhaus gewährleisten. In Anlehnung an wissenschaftliche Quellen stellt die Autorin die Terminologie, die mit „Begriffen” und Sprachverstehen verbunden ist dar. Sie zeigt Spracherwerbstheorien bei den Kindern, beschreibt Gestaltungsetappen der Äußerung der Kleinkinder. Sie weist auf die Aneignung der Namen und ihrer Bedeutung hin, also auf den Entwicklungsvorgang des semantischen Systems bei den Kindern von dritten bis zum sechsten Lebensjahr. Sie führt Erkenntnisbedürfnisse an, die zur Aneignung und zum Verstehen der Begriffe notwendig sind, wie ein aktiver und passiver Wortschatz gebildet wird. Die Autorin bespricht das Verstehensproblem der religiös-christlichen Begriffe bei den Kindern zwischen fünften und sechsten Lebensjahr, wenn der Religionsunterricht eingeführt wird. Sie lenkt unsere Aufmerksamkeit auf das Problem der Sonderbedürfnisse im Bereich der semantischen Entwicklung bei den sprachbegabten und den Kindern mit Sprachverstehensschwierigkeiten.

${ }^{51}$ Księgarnia religijna-gloria24.pl - Multimedialna Biblia dla Dzieci. Księga Rodzaju; Multimedialna Biblia dla Dzieci. Patriarchowie; Gra przypowieść o Dobrym Pasterzu; Multimedialny Quiz Biblijny. 